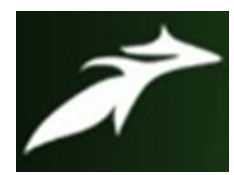

Satyajeet Kumar et al, International Journal of Advances in Agricultural Science and Technology, Vol.8 Issue.9, September-2021, pg. 32-40

ISSN: 2348-1358

Impact Factor: 6.057

NAAS Rating: 3.77

\title{
SOCIO-ECONOMIC CHARACTERISTICS AND UTILIZATION LEVEL OF COMMUNICATION MEDIA IN IMPROVED CULTIVATION PRACTICES OF PULSES BY THE FARMERS OF PURNIA DISTRICT IN BIHAR
}

\author{
Satyajeet Kumar*; Jahanara**; D.K. Bose*** \\ *- Researcher; **- Advisor (Professor \& Head of Department); ***- Co- Advisor (Associate Professor) \\ Department of Agricultural Extension and Communication, Sam Higginbottom University of Agriculture, \\ Technology and Sciences (SHUATS), Prayagraj- 211007, Uttar Pradesh, India \\ DOI: 10.47856/ijaast.2021.v08i9.005
}

\begin{abstract}
The present study is an attempt to assess the socio-economic characteristics and utilization level of communication media in improved cultivation practices of pulses by the farmers of Purnia district in Bihar.

Pulse cultivation is not prominent in this area however a large no. of farmers cultivate leguminous crop, due to availability of information or communication channel farmers were receiving proper information about practices. Primary data from 120 farmers were collected through face to face interviews. Descriptive research design had been used for the present study. Random and Purposive sampling had been used for the present study Farmers had a highest utilization in Friend, neighbor and relatives $(83.34 \%)$, Followed by radio whose utilization percentage by farmers were $75 \%$. $48.33 \%$ of farmers had Medium level of utilization Followed by $29.16 \%$ of farmers had high level utilization about improved cultivation practices of pulses.
\end{abstract}

Keywords- Socio-Economic, Utilization level, Communication media, Pulses

\section{INTRODUCTION}

Pulses are an important commodity group of crops that provide high quality protein complementing cereal proteins for pre-dominantly substantial vegetarian population of the country. Although, being the largest pulse crop cultivating country in the World, pulses share 


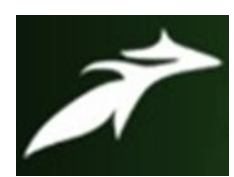

Satyajeet Kumar et al, International Journal of Advances in Agricultural Science and Technology, Vol.8 Issue.9, September-2021, pg. 32-40

ISSN: 2348-1358

Impact Factor: 6.057

NAAS Rating: 3.77

to total food grain is production is only 6-7\% in the country. The cultivation of pulses builds up a mechanism to fix atmospheric nitrogen in their root nodules and thus meet their nitrogen requirements to a great extent. In India, pulses can be produced with a minimum use of resources and hence, it becomes less costly even than animal protein. In comparison to other vegetables, pulses are rich in protein which are less expensive and can be cultivated as an inter-crop and also as mixed crop. Pulses are mostly cultivated under rainfed conditions and do not require intensive irrigation facility and this is the reason why pulses are grown in areas left after satisfying the demand for cereals/cash crops. The productivity of pulses has increased about $68 \%$ at $764 \mathrm{~kg} / \mathrm{ha}$ during 2013-14 from the level of $441 \mathrm{~kg} / \mathrm{ha}$ during 195051. It is imperative to mention that the New Agriculture Technology (NAT) introduced during mid-sixties has increased the production of food-grains from 50.82 million tonnes during 1950-51 to 265.64 million tonnes during 2013-14 with the increase in area from 97.32 million hectares to 125 million hectares. The productivity of food grains has also sharply increased to $2120 \mathrm{~kg} / \mathrm{ha}$ during 2013-14 from the level of only $522 \mathrm{~kg} / \mathrm{ha}$ during 1950-51. The potential of pulses to help address future global food security, nutrition and environmental sustainability needs has been acknowledged through the UN declaration of the 2016 International Year of Pulses. Pulses are a Smart Food as these are critical for food basket (dal-roti, dal-chawal), important source of plant protein and help address obesity, diabetes etc. In addition pulses are highly water efficient, can grow in drought prone areas and help improve soil fertility by fixing soil nitrogen.

Agricultural communicators are science communicators that deal exclusively with the diverse, applied science and business that is agriculture. An agricultural communicator is "expected to bring with him or her a level of specialized knowledge in the agricultural field that typically is not required of the mass communicator". Agricultural communication also addresses all subject areas related to the complex enterprises of food, feed, fiber, renewable energy, natural resource management, rural development and others, locally to globally. Furthermore, it spans all participants, from scientists to consumers - and all stages of those enterprises, from agricultural research and production to processing, marketing, consumption, nutrition and health. 


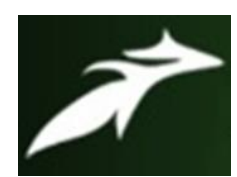

Satyajeet Kumar et al, International Journal of Advances in Agricultural Science and Technology, Vol.8 Issue.9, September-2021, pg. 32-40

ISSN: 2348-1358

Impact Factor: 6.057

NAAS Rating: 3.77

\section{RESEARCH METHODOLOGY}

The present study has been carried out during 2020-21 in purnia district, the district lies between $25.7771^{\circ} \mathrm{N}$ latitude, $87.4753^{\circ} \mathrm{E}$ longitudes. The total area of the district is 3229 sq.km out of which 815 sq. kms area is under cultivation. Out of 10 blocks in purnia district, purnia east block has been selected purposive sampling due to pulses is dominated crop and covered higher cultivable area. In preparing the list, the help of revenue personal and agricultural supervisor of the concerned area were taken for authenticity and counter check of information.12 Villages were purposely selected from purnia east block, under pulses cultivation areas. Thereafter, the 10 farmers were selected from each village on random basis. So, the samples for the present investigation were comprised of 120 respondents. The interview schedule was developed for collection of data from the selected respondents. The general of socio-economic attributes of selected respondents i.e.., age, education, land holding, annual income, family size, family type, sources of information, participation in extension activities were consisted as a first part of schedule.(Trivedi and Pareek, 1964). In third part of schedule appropriate statistical tools were used for data interpretation

\section{RESULTS AND DISCUSSION}

\subsection{Distribution of socio-economic attributes of the selected respondent}

The socio-economic attributes of the selected respondent were given in table no.1. Majority of respondents were belonged to the age group of $35-55$ i.e. $60 \%$, while $25 \%$ farmers belonged to above 55 years age group. The lowest farmers obtained under the age group of 25-35 i.e. $15 \%$. The maximum respondents $(33.33 \%)$ were qualified intermediate followed by graduate $(19.16 \%)$, while $16.67 \%$ respondents had qualification up to high school. $10 \%$ respondents had qualification up to middle school, while $8.33 \%$ of respondents had qualification up to primary and post graduate level respectively. And out 120 respondents only $4.17 \%$ farmers were illiterate. When we talk about size of land holdings then it was found through survey that $53.33 \%$ of farmers had large size of land holdings followed by small size of land holding $(26.67 \%)$, and $20 \%$ of farmers having marginal size of land 


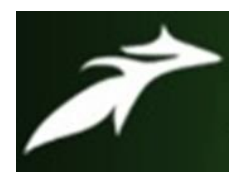

Satyajeet Kumar et al, International Journal of Advances in Agricultural Science and Technology, Vol.8 Issue.9, September-2021, pg. 32-40

ISSN: 2348-1358 Impact Factor: 6.057 NAAS Rating: 3.77

holding. The majority of respondents $(45.83 \%)$ had medium level of annual income i.e. 80000-120000. Followed by high level of annual income (37.50\%) i.e. above 120000, and (16.67\%) respondent had low level of annual income. Among all the respondents, majority of respondent $(61.67 \%)$ belonged to large size of family. While $38.33 \%$ of respondents were belonged to small size of family. The majority of respondents (53.33\%) had High level of knowledge about sources of information. And the majority of respondents were belonged to medium level of participation in extension activities.

Table no. 1 - Distribution of respondents according to their Socio- Economic Characteristics.

\begin{tabular}{|l|l|l|}
\hline S.NO. & \multicolumn{1}{|c|}{ CATEGORY } & PERCENTAGE \\
\hline $\mathbf{1 .}$ & Age & \\
\hline & $25-35$ & 15 \\
\hline & $36-55$ & 60 \\
\hline & Above 55 & 25 \\
\hline $\mathbf{2}$ & Education & \\
\hline & Illiterate & 4.17 \\
\hline & Primary & 8.33 \\
\hline & Middle & 10 \\
\hline & High school & 16.67 \\
\hline & Intermediate & 33.33 \\
\hline & Graduate & 19.16 \\
\hline & Post graduate & 8.33 \\
\hline $\mathbf{3}$ & Size of land holding & \\
\hline & Marginal & 20 \\
\hline & Small & 26.67 \\
\hline & Large & 53.33 \\
\hline
\end{tabular}




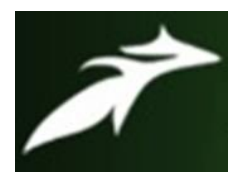

Satyajeet Kumar et al, International Journal of Advances in Agricultural Science and Technology, Vol.8 Issue.9, September-2021, pg. 32-40

ISSN: $2348-1358$

Impact Factor: 6.057

NAAS Rating: 3.77

\begin{tabular}{|l|l|l|}
\hline $\mathbf{4}$ & Annual income & \\
\hline & Low & 16.67 \\
\hline & Medium & 45.83 \\
\hline & High & 37.50 \\
\hline $\mathbf{5}$ & Family Size & \\
\hline & Small size & 38.33 \\
\hline & Large size & 61.67 \\
\hline $\mathbf{6}$ & Family types & \\
\hline & Nuclear & 38.33 \\
\hline & Joint & 61.67 \\
\hline $\mathbf{7}$ & Sources of information & \\
\hline & Low & 13.33 \\
\hline & Medium & 33.33 \\
\hline & High & 53.33 \\
\hline $\mathbf{8}$ & Participation in extension activities & \\
\hline & Low & 18.33 \\
\hline & Medium & 36.67 \\
\hline & High & 35 \\
\hline
\end{tabular}

\subsection{Utilization level of communication media}

17 communication channels used by the respondents to seek information about improved cultivation practices were identified in this study. Pattern of use of communication media can be helpful in diffusing agricultural information among them effectively. For this purpose, data regarding extent use of communication media by pulses grower were collected. 


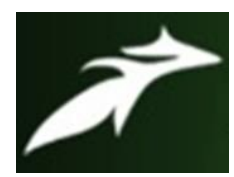

Satyajeet Kumar et al, International Journal of Advances in Agricultural Science and Technology, Vol.8 Issue.9, September-2021, pg. 32-40

ISSN: 2348-1358

Impact Factor: 6.057

NAAS Rating: $\mathbf{3 . 7 7}$

Table no. 2- Distribution of the respondents according to the extent of utilization of communication media

\begin{tabular}{|c|c|c|c|c|c|c|c|}
\hline \multirow{2}{*}{$\begin{array}{l}\text { Sr. } \\
\text { No } \\
\text { A. }\end{array}$} & \multirow{3}{*}{$\begin{array}{l}\text { Category } \\
\text { Interpersonal Media } \\
\end{array}$} & \multicolumn{6}{|c|}{ Extent of utilization of communication media } \\
\hline & & \multicolumn{2}{|c|}{ Always } & \multicolumn{2}{|c|}{ Sometimes } & \multicolumn{2}{|c|}{ Never } \\
\hline & & $\mathrm{F}$ & $\%$ & $\mathrm{~F}$ & $\%$ & $\mathrm{~F}$ & $\%$ \\
\hline 1 & $\begin{array}{lll}\begin{array}{l}\text { Friends, } \\
\text { relatives }\end{array} & \text { neighbours } \& \\
\end{array}$ & 100 & $83.33 \%$ & 20 & $16.67 \%$ & 0 & $0 \%$ \\
\hline 2 & Agril. Univ. Scientists & 31 & $25.83 \%$ & 70 & $58.33 \%$ & 19 & $15.84 \%$ \\
\hline 3 & Local leader & 65 & $54.18 \%$ & 35 & $29.16 \%$ & 20 & $16.66 \%$ \\
\hline 4 & Non gov. organization & 12 & $10 \%$ & 22 & $18.33 \%$ & 86 & $71.67 \%$ \\
\hline 5 & Village level worker & 42 & $35 \%$ & 50 & $41.67 \%$ & 28 & $23.33 \%$ \\
\hline 6 & Agril. Extension officer & 30 & $25 \%$ & 50 & $41.67 \%$ & 40 & $33.33 \%$ \\
\hline 7 & Agril assistants. & 42 & $35 \%$ & 54 & $45 \%$ & 24 & $20 \%$ \\
\hline B & Mass media & & & & & & \\
\hline 8 & Radio & 90 & $75 \%$ & 20 & $16.67 \%$ & 10 & $8.33 \%$ \\
\hline 9 & Television & 40 & $33.33 \%$ & 50 & $41.67 \%$ & 30 & $25 \%$ \\
\hline 10 & Newspaper & 32 & $26.66 \%$ & 63 & $52.50 \%$ & 25 & $20.83 \%$ \\
\hline 11 & Smartphone + Internet & 55 & $45.84 \%$ & 30 & $25 \%$ & 35 & $29.16 \%$ \\
\hline 12 & Agril. Magazine & 19 & $15.83 \%$ & 48 & $40 \%$ & 53 & $44.16 \%$ \\
\hline 13 & Leaflets & -- & & 26 & $21.66 \%$ & 94 & $79.34 \%$ \\
\hline 14 & Folders & -- & & 16 & $13.34 \%$ & 104 & $86.66 \%$ \\
\hline 15 & Agril. Exhibition & 13 & $10.83 \%$ & 45 & $37.50 \%$ & 62 & $51.66 \%$ \\
\hline 16 & Tours & 4 & $3.33 \%$ & 20 & $16.67 \%$ & 96 & $80.00 \%$ \\
\hline 17 & Demonstration & 30 & $25.00 \%$ & 40 & $33.33 \%$ & 50 & $41.67 \%$ \\
\hline
\end{tabular}




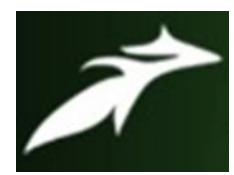

Satyajeet Kumar et al, International Journal of Advances in Agricultural Science and Technology,

Vol.8 Issue.9, September-2021, pg. 32-40

ISSN: 2348-1358

Impact Factor: 6.057

NAAS Rating: 3.77

Table no. 3 - Distribution of respondents according to their Utilization Level of

Communication media.

\begin{tabular}{|l|l|l|}
\hline S.NO. & \multicolumn{1}{|c|}{ CATEGORY } & PERCENTAGE \\
\hline 1 & Low & 22.50 \\
\hline 2 & Medium & 48.33 \\
\hline 3 & High & 29.17 \\
\hline
\end{tabular}

In table no. 2 it is shown that majority of respondents had medium level of utilization of communication media, while $29.17 \%$ of respondents had high level of utilization and $22.50 \%$ of the respondents had low level of utilization in communication media.

Figure no. 1 - Distribution of respondents according to their Utilization Level of Communication media.

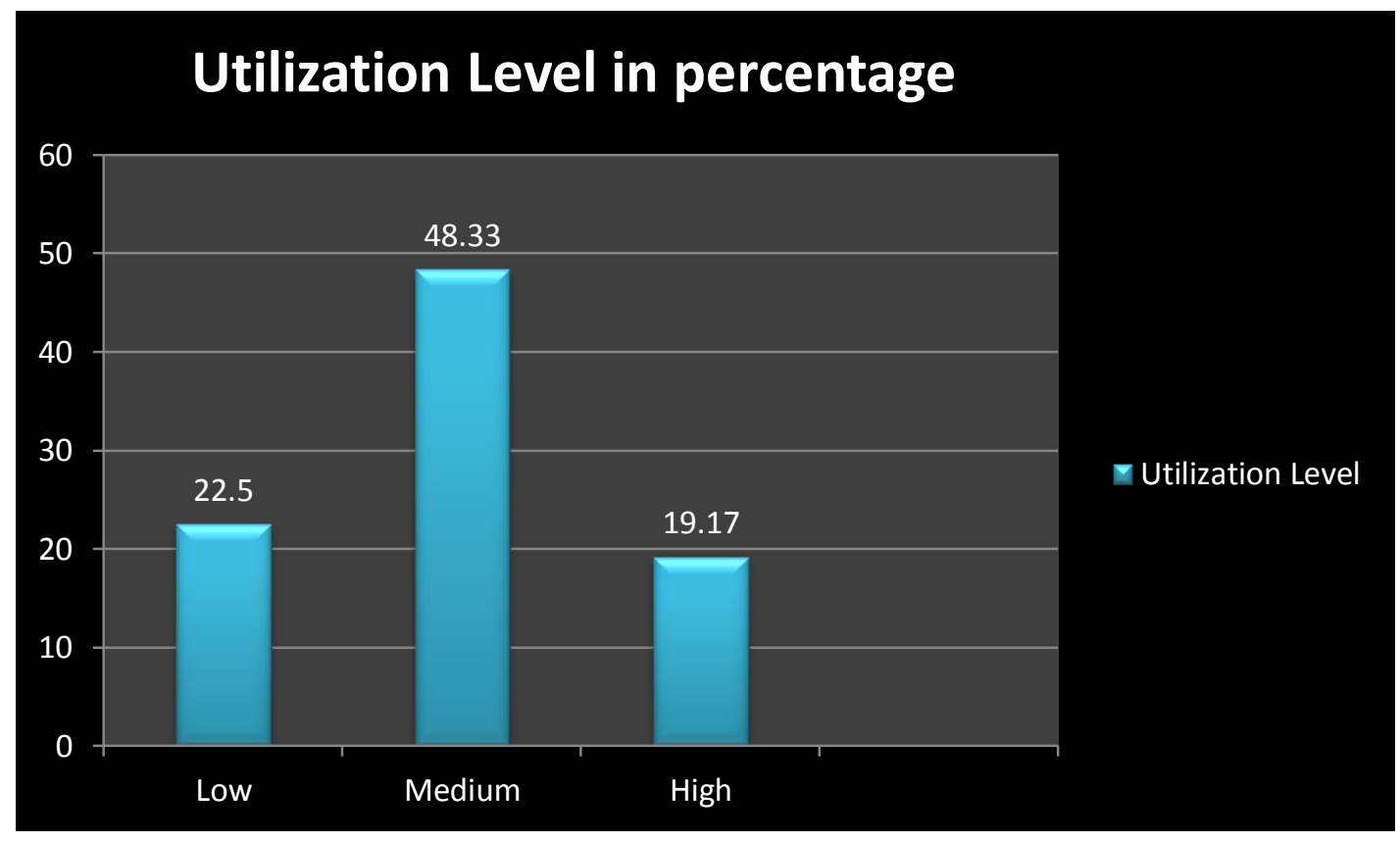




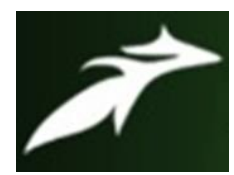

Satyajeet Kumar et al, International Journal of Advances in Agricultural Science and Technology, Vol.8 Issue.9, September-2021, pg. 32-40

ISSN: 2348-1358

Impact Factor: 6.057

NAAS Rating: 3.77

\section{Conclusion}

Based on the findings of the study, it was concluded that majority of the respondents were middle age group had large size of land holding. Majority of respondents were qualified more than high school level. Maximum number of respondents had medium level of income. Majority of respondents possess high level of source of information. And majority of respondents had medium level of utilization of communication in adoption of improved cultivation practices of pulses. Reason behind the majority of respondent having medium level of utilization is that majority of respondents were of middle age group and people of this age in rural areas are not so fluent in using smartphones ,maximum respondents had educational qualification only up to $12^{\text {th }}$, lack of technical knowledge and unavailability of print materials are some reason behind medium level of utilization

\section{CONSENT}

Informed consent of the entire respondents was taken before conducting the personal interview.

\section{COMPETING INTERESTS}

Authors have declared that no competing interests exist.

\section{REFERENCES}

[1]. Balaji, V., Meera, S.N., and Dixit, Sreenath. (2007), ICT enabled knowledge sharing in support of extension: addressing the agrarian challenges of the developing world threatened by climate change, with a case study from India, SAT eJournal, eJournal.icrisat.org, December, 2007, 4(1).

[2]. Down to earth (2014). http://www.downtoearth.org.in/news/indias-deepening-farm-crisis76-farmerswant-to-give-up-farming-shows-study-43728.

[3]. Meena B S., (2010), Communication sources, credibility and utilization pattern among farmers. Rajasthan Journal of Extension Education. 17 \& 18: 40-43

[4]. Patil, V.C., Gelb, Ehud, Yaduraju, N.T., Moni, M. and Patil, Roopa. S., (2009), Web based agriculture in India, http://www.fao.org/docs/eims/upload//257364/Patil_presentation.pdf

[5]. PC, GoI, (2007), Recommendations of working group on agricultural extension for formulation of eleventh five year plan (2007-12), Planning Commission, Government of India, New Delhi. http://planning commission.nic.in/plans/planrel/11thf.htm 


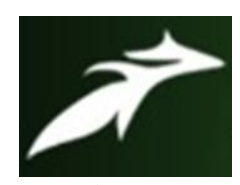

Satyajeet Kumar et al, International Journal of Advances in Agricultural Science and Technology, Vol.8 Issue.9, September-2021, pg. 32-40

ISSN: 2348-1358

Impact Factor: 6.057

NAAS Rating: 3.77

[6]. Saravanan R. (2010). ICTs for Agricultural Extension: Global Experiments, Innovations and Experiences. New India Publishing Agency, New Delhi

[7]. ICAR (2016). Reaching out to farmers through e extension initiatives, Flyer, Indian Council of Agricultural Research (ICAR), January 14, New Delhi. Available: https://www.facebook.com/InAgrisearch/photos/pcb.892000694230763/892000400897459/?type=3\&t heater [June 2,2016]

[8]. GOI (2015). Two Mobile Apps Launched for Farmers, Press Information Bureau, Government of India December http://pib.nic.in/newsite/PrintRelease.aspx?relid=133861 [June 9,2016]

[9]. Meena, K.C., Chand, S. and Meena, N.R (2013). Impact of social media in sharing information on issues related to agriculture among researchers and extension professionals Adv. Appl. Res, 5(2): 166 169.

[10].Ansari MA, Sunetha S. Agriculture information needs of farm women: A study in State of North India, African Journal of Agricultural Research . 2014; 9(19):1454 - 1460. 